ORIGINAL

\title{
ACTH response to desmopressin in a patient with acromegaly; Expression of corticotropin-releasing factor, urocortins and vasopressin V1b receptor in GH-producing pituitary adenoma
}

\author{
Zenei Arihara ${ }^{1)}$, Kanako Sakurai $^{1)}$, Yoshinori Osaki ${ }^{1)}$, Hiroshi Fukazawa ${ }^{1)}$, Shozo Yamada ${ }^{2)}$, Naoko Inoshita ${ }^{3)}$, \\ Osamu Murakami ${ }^{4)}$, Koji Ohba ${ }^{5)}$ and Kazuhiro Takahashi ${ }^{5)}$ \\ 1) Department of Endocrinology and Metabolism, Suifu Hospital, Mito 311-4141, Japan \\ 2) Department of Hypothalamic and Pituitary Surgery, Toranomon Hospital, Tokyo 105-8470, Japan \\ 3) Department of Pathology, Toranomon Hospital, Tokyo 105-8470, Japan \\ 4) Division of Nephrology, Endocrinology and Vascular Medicine, Tohoku University School of Medicine, Sendai 980-8574, Japan \\ 5) Department of Endocrinology and Applied Medical Science, Tohoku University Graduate School of Medicine, Sendai 980-8575, \\ Japan
}

\begin{abstract}
GH-producing pituitary adenomas frequently co-produce other certain anterior pituitary hormones, such as prolactin (PRL). In contrast, GH-producing adenomas which express all of corticotropin-releasing factor (CRF), urocorin1 (Ucn1) and urocortin3 (Ucn3) have not been reported. A 39-year-old woman was admitted for evaluation of the pituitary tumor. The diagnosis of acromegaly was confirmed by elevated serum GH and IGF-I levels, and the absence of GH suppression by oral glucose tolerance test. ACTH response to desmopressin (DDAVP) was observed (plasma ACTH levels increased from 13.9 to $50.4 \mathrm{pg} / \mathrm{mL}$ at $90 \mathrm{~min}$ ). Although it is known that ACTH response to DDAVP is considerably useful for the diagnosis of ACTH-dependent Cushing's syndrome, the diagnosis of Cushing's disease was not supported by the criteria. The patient underwent transsphenoidal resection of the pituitary tumor. Immunohistological examination confirmed a GHand PRL-producing adenoma, whereas ACTH was negative. ACTH response to DDAVP disappeared after tumor removal. To determine the cause of preoperative ACTH response to DDAVP, we examined expression of CRF family peptides and vasopressin V1b receptor in the pituitary adenoma by immunohistochemistry. Immunohistochemistry revealed positive immunostaining for CRF, Ucn1, Ucn3 and vasopressin V1b receptor in the adenoma. These observations raised the possibility that DDAVP caused an ACTH response, perhaps via the paracrine effects of tumor-derived CRF and Ucn1. When ACTH response to DDAVP is observed in patients with pituitary tumor, not only the direct effect of DDAVP on ACTH secretion, but also a possible involvement of CRF and/or urocortins expressed in the pituitary adenoma, should be considered.
\end{abstract}

Key words: Corticotropin-releasing factor, Urocortin, Acromegaly, Cushing’s disease, Desmopressin

GH-PRODUCING pituitary adenomas frequently coproduce other certain anterior pituitary hormones, such as PRL and the alpha-subunit of the glycoprotein hormones [1]. However, GH-producing adenomas with concomitant ACTH production are extremely rare. Indeed, pituitary adenomas are classified into following three types by the hormone content; GH-PRL-TSH family, ACTH family and gonadtropin family [2]. In general, adenomas of each family do not usually secrete

Submitted May 23, 2011; Accepted Aug. 23, 2011 as EJ11-0038 Released online in J-STAGE as advance publication Sep. 8, 2011

Correspondence to: Zenei Arihara, M.D., Ph.D., Department of Endocrinology and Metabolism, Suifu Hospital, 1-1, Akatsuka, Mito, Ibaraki, 311-4141, Japan. E-mail: arihara-zen@umin.ac.jp another family's hormones.

The number of cases of Cushing's disease without typical Cushing's syndrome has recently been increasing because some of pituitary incidentalomas were revealed to be secreting certain pituitary hormones, such as ACTH. Therefore, the difficulties of the preoperative diagnosis are sometimes underlying in ACTHproducing pituitary adenomas [3]. Desmopressin (DDAVP), which is a long-acting vasopressin analogue acting mainly on the $\mathrm{V} 2$ receptor with a weak reactivity for the V1b receptor, elicits an ACTH and cortisol release in patients with Cushing's disease, but not in the majority of normal, obese or depressed subjects, or patients with ectopic ACTH syndrome. Testing 
with DDAVP is, therefore, considerably useful as the screening for Cushing's disease [4-6]. In the patient with ACTH-producing adenoma, DDAVP stimulates ACTH via V1b receptors which exist abundantly in corticotroph adenoma [6]. DDAVP test is included in the initial screening procedure of the diagnostic criteria for Cushing's disease reported by the Ministry of Health, Labour, and Welfare of Japan, which is not available in English, but reported in two articles [7, 8].

Urocortins are known as members of the CRF family neuropeptides, and there are at least three types of urocortins; Ucn1, urocortin2 (Ucn2) and Ucn3 [9, 10]. The presence of Ucn 1 and Ucn3 peptides has been demonstrated in human tissues, such as brain, pituitary and various peripheral tissues [11-13]. Biological actions of CRF family peptides are mediated via two types of $G$ protein-coupled receptors, CRF type 1 receptor (CRF1R) and CRF type 2 receptor (CRF2R) $[14,15]$. Ucn 1 is known to bind with high affinity to both CRF1R and CRF2R, but this peptide has a 6-fold higher affinity for CRF1R than CRF, and approximately 40-fold higher affinity for CRF2R than CRF $[9,16]$. Ucn3 was also associated with high affinity for CRF2R but did not bind to CRF1R [10]. CRF1R deficient mice failed to exhibit the characteristic hormonal response to the stress due to a disruption of the hypothalamic-pituitary-adrenal axis [17]. CRFR1 not but CRF2R plays an important role of ACTH secretion from pituitary gland.

Here we report a case of acromegaly with ACTH response to DDAVP. We investigated the expression of CRF, urocortins and vasopressin V1b receptor in the pituitary tumor by immunohistochemistry to clarify the cause of this ACTH reaction to DDAVP.

\section{Methods}

\section{Endocrine tests}

Following hormone assays were performed by using the methods shown in the parentheses; serum GH (immunoradiometric assay, GH “Daiichi” kit, TFB Inc., Tokyo, Japan), serum IGF-I (immunoradiometric assay, IGF-I IRMA “Daiichi” kit, TFB Inc.), plasma ACTH (enhanced chemiluminescence immunoassay, Elecsys ACTH kit, Roche Diagnostics Japan, Tokyo, Japan) and serum cortisol (RIA, cortisol kit “TFB”, TFB Inc.). Dynamic hormone tests were performed after overnight fasting. An indwelling catheter was inserted in a forearm vein at 8:00 h, and blood samples were collected before and after the injection of following stimulators; DDAVP (Desmopressin injection 4 kyowa, Kyowa Hakko Kirin Co. Ltd., Tokyo, Japan), CRF (hCRH injection $100 \mu \mathrm{g}$ “Tanabe,” Mitsubishi Tanabe Pharma Co., Osaka, Japan), and TRH (TRH injection $0.5 \mathrm{mg}$ “Tanabe,” Mitsubishi Tanabe Pharma Co.).

\section{Histological analysis}

Surgery was performed at the Department of Hypothalamic and Pituitary surgery, Toranomon Hospital. Pathological diagnosis and immunohistochemistry of GH, ACTH, PRL, LH, FSH, TSH, Ki67 (MIB-1) and cytokeratin (CAM5.2) were performed at the Department of Pathology, Toranomon hospital in Tokyo, Japan. Immunohistochemistry of CRF, Ucn1, Ucn3 and vasopressin V1b receptor was performed at the Department of Endocrinology and Applied Medical Science, Tohoku University Graduate School of Medicine.

The pituitary tumor was fixed in formalin. Sections were stained for hematoxylin and eosin (H.E.) and immunostained for pituitary hormones, MIB-1 (Ki-67), cytokeratin, CRF, Ucn1, Ucn3 and vasopressin V1b receptor by the avidin-biotin-peroxidase complex (ABC) technique. Following antibodies were used: the polyclonal antibodies to GH (1:800; Dakopatts, Glostrup, Denmark), ACTH (1:1600; Dakopatts), CRF (1:1000) [18], Ucn1 (1:1000) [12, 19], Ucn3 (1:1000) [13], vasopressin V1b receptor (1:100, $2 \mu \mathrm{g} /$ mL; Santa Cruz Biotechnology, Inc., Santa Cruz, CA, USA) and monoclonal antibodies to prolactin (1:1000; Immunotech, Marseille, France), $\beta$-subunit of LH (1:1000; Immunotech), FSH (1:1000; Immunotech), TSH (1:100; Chemicon, Temecula, CA), Ki-67, clone MIB-1 (1:100, Lot.012; DAKO, Kyoto, Japan) and CAM5.2 (Becton Dickinson, San Jose, CA) [20]. The antibodies against CRF, Ucn1 and Ucn3 showed no significant cross-reaction with other CRF family peptides, respectively [11-13, 19].

The patient gave her informed consent for all the studies related to her case. The study was approved by the ethics committee of each hospital and institute.

\section{Results}

\section{Case report}

A 39-year-old woman was admitted to our hospital because of a pituitary tumor detected by brain MRI, which was performed to examine the cause of vertigo. 

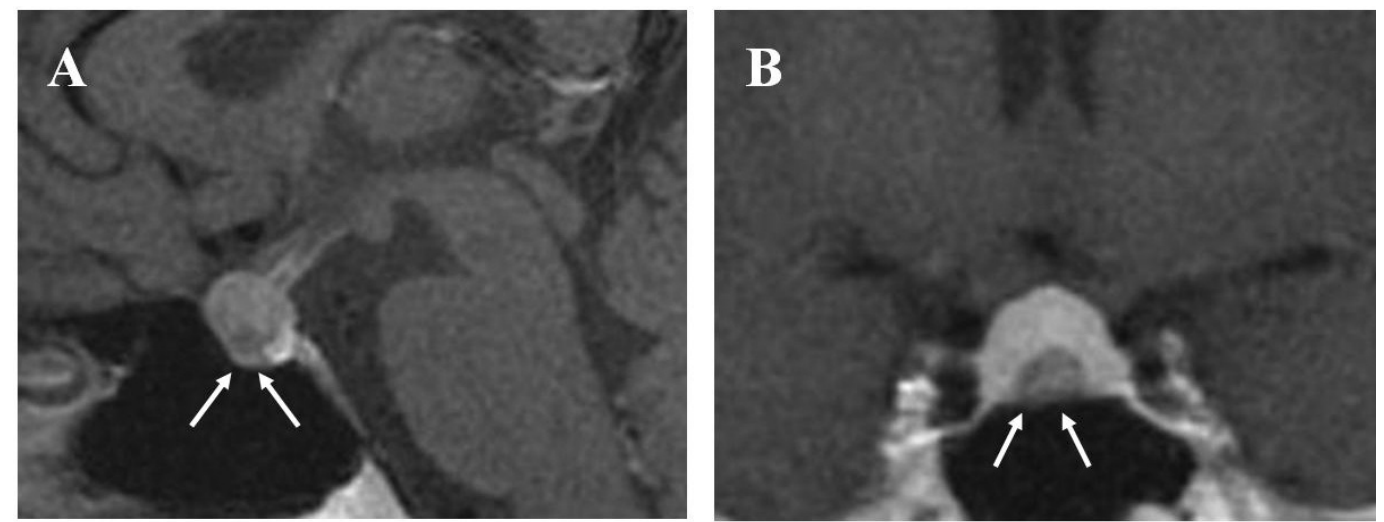

Fig. 1 T1-weighted enhancing MRI of the patient. Shown is the sagittal section (A) and the coronal section (B). A less enhancing lesion $1.3 \mathrm{~cm}$ in diameter suggesting a pituitary adenoma (indicating arrows) was observed in the bottom of the central wedge of the pituitary.

Her height and body weight were $159.3 \mathrm{~cm}$ and 54.4 $\mathrm{kg}$, respectively. She lacked in characteristic disfigurement of either acromegaly or Cushing's syndrome. Her blood pressure was 90/54 mmHg. A goiter was found. No abnormal findings were observed in her chest and abdomen. Neurological examination including visual field showed no abnormalities.

A less enhancing pituitary adenoma being $13 \mathrm{~mm}$ in diameter was demonstrated in the bottom of the central wedge of the pituitary by MRI (Fig. 1).

Both serum GH and IGF-I levels were elevated to $2.48 \mathrm{ng} / \mathrm{mL}$ (reference range 0.28-1.64 ng/mL), and 285 $\mathrm{ng} / \mathrm{mL}$ (reference range $100-250 \mathrm{ng} / \mathrm{mL}$ ), respectively. Serum PRL levels were normal $(8.5 \mathrm{ng} / \mathrm{mL}$, reference range 6.12-30.54 ng/mL). Both plasma ACTH and cortisol levels were normal (ACTH $28.0 \mathrm{pg} / \mathrm{mL}$, reference range 7.4-55.7 pg/mL; and cortisol $10.0 \mu \mathrm{g} / \mathrm{dL}$, reference range 4.0-18.3 $\mu \mathrm{g} / \mathrm{dL}$, respectively). Urinary free cortisol excretion was within normal range $(34.5 \mu \mathrm{g} /$ day, reference range 11.2-80.3 $\mu \mathrm{g}$ /day). The results of the thyroid function test were consistent with hypothyroidism and Hashimoto's thyroiditis (TSH $8.03 \mathrm{mU} / \mathrm{mL}$, free T3 $3.35 \mathrm{pg} / \mathrm{mL}$, free T4 $0.91 \mathrm{ng} / \mathrm{dL}$, TgAb $832 \mathrm{IU} / \mathrm{L}$ and TPOAb $>600 \mathrm{IU} / \mathrm{L}$ ). The findings of the thyroid ultrasonogram were corresponding to the diagnosis of Hashimoto's thyroiditis. Treatment with thyroxine was started and euthyroidism was maintained. The other hormonal data were within normal range. No suppression of GH (Fig. 2A) was observed during the oral glucose tolerance test (OGTT), and a paradoxical response of GH (from $3.65 \mathrm{ng} / \mathrm{dL}$ to $16.4 \mathrm{ng} / \mathrm{dL}$ ) to TRH (500 $\mu \mathrm{g}$

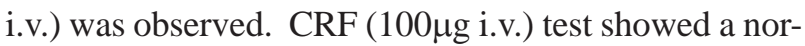
mal ACTH response (Fig. 2B). DDAVP test showed that DDAVP ( $4 \mu \mathrm{g})$ increased plasma ACTH and cortisol levels from $13.9 \mathrm{pg} / \mathrm{mL}$ to $50.4 \mathrm{pg} / \mathrm{mL}$ at $90 \mathrm{~min}$, and from $6.5 \mu \mathrm{g} / \mathrm{dL}$ to $14.0 \mu \mathrm{g} / \mathrm{dL}$ at $90 \mathrm{~min}$, respectively (Fig. 2C). No increase in serum GH levels was observed in DDAVP test (data not shown). Paradoxical increment of GH was not observed in GnRH and CRF tests. Plasma cortisol at midnight (23 o'clock) was 1.4 $\mu \mathrm{g} / \mathrm{dL}$. Overnight dexamethasone administration of 0.5 mg suppressed cortisol completely ( $<1.0 \mu \mathrm{g} / \mathrm{dL}$ ). Thus the diagnosis of acromegaly was confirmed, whereas the diagnostic criteria of Cushing's disease were not fulfilled. The patient underwent surgical treatment of the pituitary tumor.

Both serum IGF-I and GH levels were restored to normal and serum GH level was suppressed to undetectable level $(<0.1 \mathrm{ng} / \mathrm{mL})$ by OGTT (Fig. 2A) after surgery. Dexamethasone was supplemented at a dose of $0.5 \mathrm{mg}$ a daily. CRF test was performed one week after the dexanethasone supplement was withdrawn. ACTH was responded to CRF from $31.6 \mathrm{pg} / \mathrm{mL}$ to 55.3 $\mathrm{pg} / \mathrm{mL}$ (Fig. 2B). DDAVP test showed no response of ACTH and cortisol (Fig. 2C). Postoperative brain MRI demonstrated complete removal of the pituitary tumor.

\section{Immunohistochemistry}

Histopathological examinations using H.E. staining demonstrated an eosinophilic adenoma (Fig. 3A). MIB-1/Ki-67 labeling index was 1\%. CAM5.2 staining showed a characteristic perinuclear dot-like pattern. Immunohistochemistry demonstrated diffuse, strongly positive immunostaining for GH (Fig. 3B) and weakly positive immunostaining for PRL (Fig. 3C) and TSH (positive ratios, $10 \%$ and $1 \%$, respectively) in the ade- 

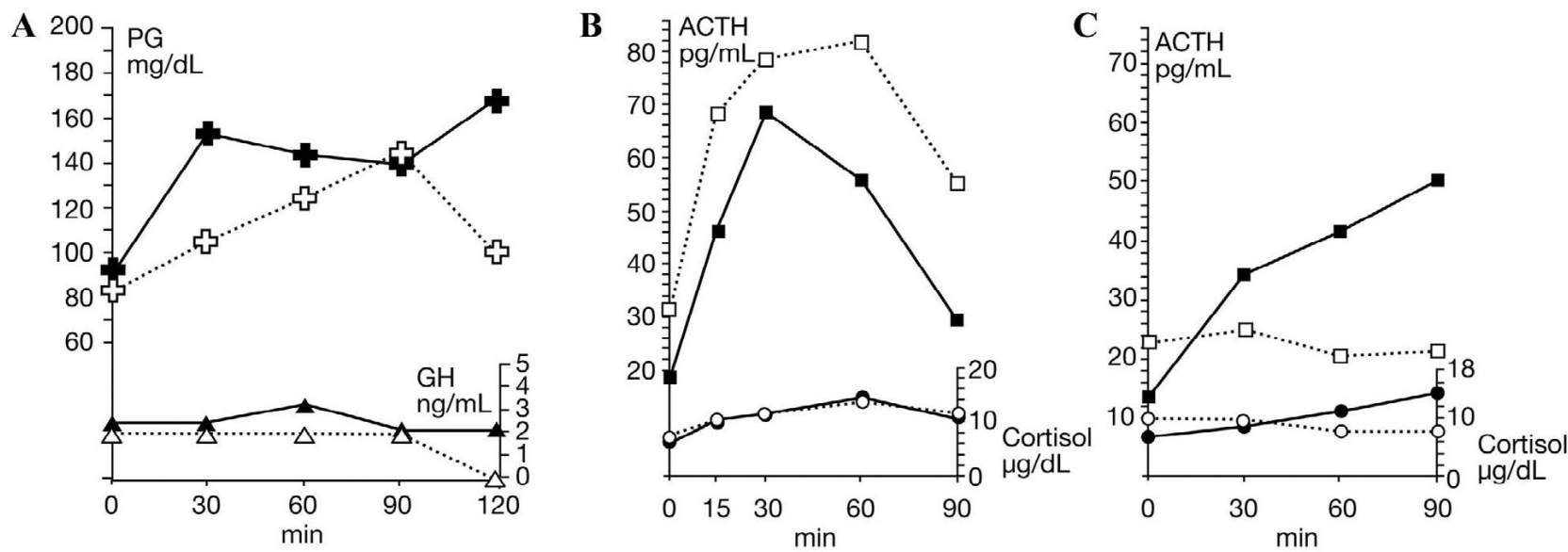

Fig. 2 Dynamic endocrine test results, performed pre- and post-operatively. Changes in serum GH and plasma glucose (PG) levels in the oral glucose tolerance test (A). Closed cross: pre-operative PG; open cross: post-operative PG; closed triangle: pre-operative GH;

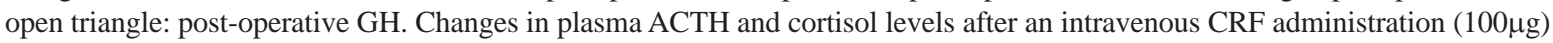
(B). Changes in plasma ACTH and cortisol levels after an intravenous DDAVP administration (4 $\mu \mathrm{g})(\mathrm{C})$. Closed square: preoperative ACTH; open square: post-operative ACTH; closed circle: pre-operative cortisol, open circle: post- operative cortisol.
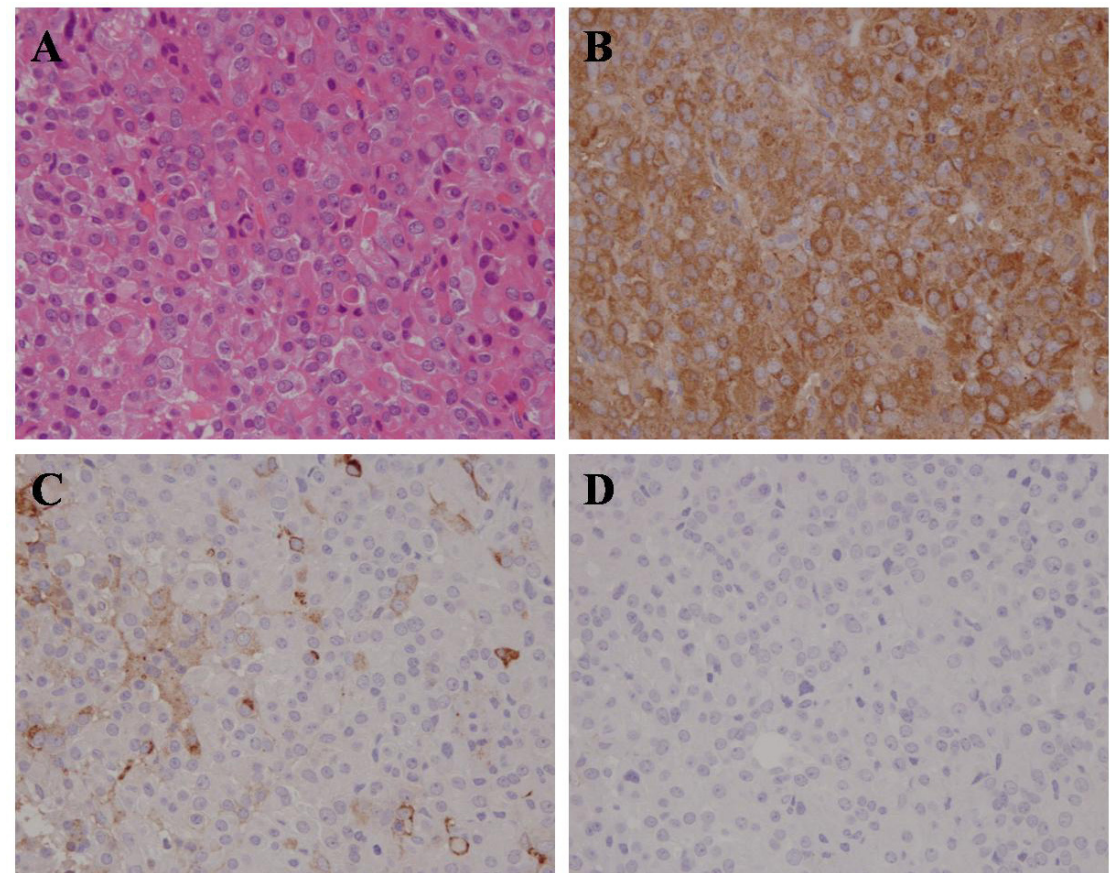

Fig. 3 H.E. staining and immunohistochemistry of anterior pituitary hormones in the adenoma. H.E. staining (A). Immnohistochemistry showed marked positive immunostaining for GH (B), positive for PRL (C), negative for ACTH (D).

noma, whereas the immunostaining for ACTH (Fig. 3D) and LH/FSH was negative.

Immunohistiochemistry of ACTH secretagogues showed that immunostaining of all CRF, Ucn1 and Ucn3 was positive in the pituitary tumor (Fig. 4A, B, C). Particularly, Ucn1 immunostaining in the tumor was found to be the most marked among three ACTH secretagogues. Immnohistochemistry of vasopressin V1b showed a weak but positive immunostaining for V1b receptor in the adenoma (Fig. 5A). Negative control using normal rabbit IgG showed no immunostaing (Fig. 5B). 

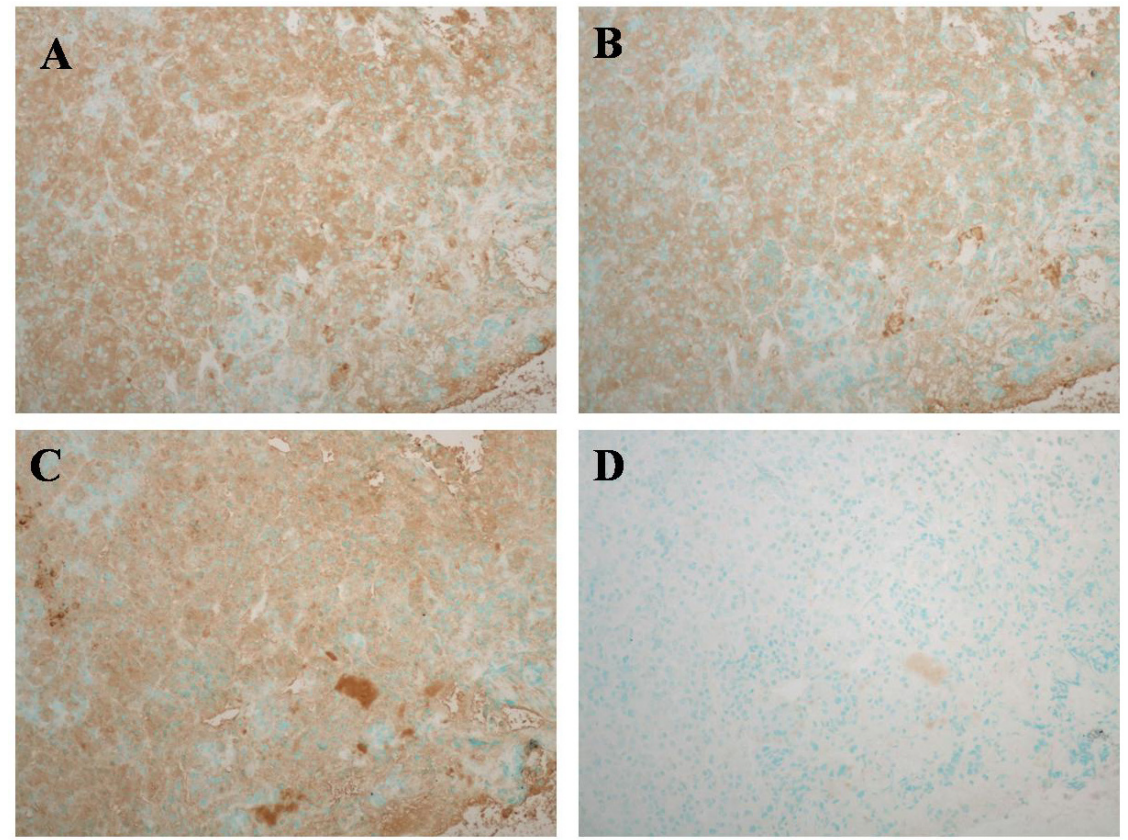

Fig. 4 Immunohistochemistry of CRF family peptides in the pituitary adenoma. Immunohistochemistry showed marked positive immunostaining for Ucn1 (A), positive for Ucn3 (B), and positive for CRF (C). Negative control of normal rabbit serum (D).
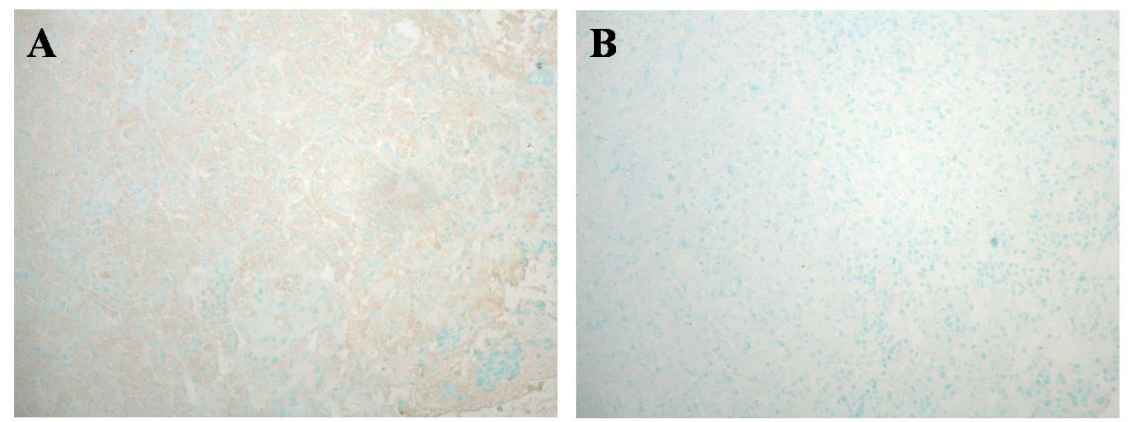

Fig. 5 Immunohistochemistry of vasopressin V1b receptor in the pituitary adenoma. Immunohistochemistry showed a weak but positive immunostaining for V1b receptor (A). Negative control of normal rabbit IgG (2 $\mu \mathrm{g} / \mathrm{mL}$, Santa Cruz Biotechnology, Inc) (B).

\section{Discussion}

This patient with a pituitary tumor lacked in characteristic disfigurement of either acromegaly or Cushing's syndrome. Subclinical pituitary disease, such as subclinical acromegaly or subclinical Cushing's disease, was therefore suspected. DDAVP test was performed in order to screen for subclinical Cushing's disease. It is known that DDAVP test is considerably useful as the screening for ACTH-dependant Cushing's syndrome [3-6]. In Japan, DDAVP test is included in screen- ing tests for (subclinical) Cushing's disease [7, 8]. The ACTH response to DDAVP is specific to patients with corticotroph adenoma, and the responder has not been reported previously among patients with other types of pituitary tumors. In the diagnostic criteria for Cushing's disease in Japan [7, 8], more than 1.5-fold increase in plasma ACTH levels after $4 \mu \mathrm{g}$ DDAVP injection is considered to be a positive finding. In the present case, a 3.6-fold increase in plasma ACTH levels was observed 90 min after $4 \mu \mathrm{g}$ DDAVP injection (i.v.). Such a large increase in plasma ACTH levels 
was unlikely to be a non-specific response during this test. This is the first report on the responder of $\mathrm{ACTH}$ to DDAVP with GH-producing adenoma. Furthermore, we wished to clarify the cause for the ACTH response in DDAVP test.

The diagnosis of this patient was confirmed by the histological examination as GH- and PRL-producing adenoma. However, no evidence of co-production of ACTH from the adenoma was found in the immunohistological examinations. The pituitary tumor was considered to be completely removed by the transsphenoidal surgery because of post-operative normalized IGF-I levels and suppression of GH by OGTT. Although the ACTH response to DDAVP disappeared, ACTH increased from $31.6 \mathrm{pg} / \mathrm{mL}$ to $82.0 \mathrm{pg} / \mathrm{mL}$ in CRF test after the surgery. The post-operative hypofunction of the hypothalamo-pituitary-adrenal axis was therefore unlikely. Thus, the source of ACTH responded to DDAVP before the surgery was considered to be derived from non-neoplastic portion of the pituitary gland. There have been some reports which show that $\mathrm{CRH}$ and Ucn1 are produced in pituitary gland and may regulate ACTH secretion in a paracrine/autocrine fashion [11, 21, 22]. Therefore, we postulated that paracrine effects by the adenoma affected secretion of ACTH from normal pituitary gland in this case.

Immunohistochemistry demonstrated the expression of CRF, Ucn1 and Ucn3, well-known ACTH secretagogues, in the adenoma. The previous study demonstrated expression of CRF mRNA on paraffin sections using the quantitative in situ hybridization method in approximately $86 \%$ of human pituitary corticotroph adenomas [23]. There has been no report, however, on CRF expression in other types of pituitary adenomas. It was reported that Ucn1-immunoreactive cells were detected in the anterior pituitary gland and over $75 \%$ of Ucn1 cells expressed GH immunoreactivity [11]. Among 52 cases of pituitary adenomas, however, Ucn1 immunoreactivity was detected only in two cases; one case of GH-producing adenoma and one case of nonfunctioning adenoma [11]. The presence of Ucn3 immunoreactivity and mRNA was demonstrated in human pituitary by RIA and RT-PCR [13], whereas Ucn3 expression has not been studied in pituitary tumors. Our case is therefore a very rare case of GH- and PRL-producing pituitary adenoma, which has been demonstrated to express CRF, Ucn1 and Ucn3.

The pituitary tumor in our case was a single adenoma without boundary, and almost whole cells were positive for GH, CRF, Ucn1 and Ucn3 by immunohistochemistry. Therefore, it might be considered that GH and CRF family neuropeptides were produced concomitantly from the same cells although the double stains for GH and CRF family peptides were not examined. Tahara et al. reported a case in which ACTH and GH were concomitantly produced from the pituitary adenoma [24]. They showed the aberrant expression of transcription factors NeuroD1 and Pit-1 by in situ hybridization, and proposed it for the concomitant production of ACTH and GH. NeuroD1/ß1 and Pit-1 are the transcription factors implicated in the development of individual pituitary cell types to a corticotroph and somatotroph stem cell, respectively [2]. CRF is produced by rat corticotropes [22] and human pituitary corticotroph adenoma [23], and Ucn1 is produced by GH producing pituitary cells [11]. The transcriptional factor, Brn-2, plays an important role in the development of CRF neurons in the hypothalamus [25]. Further studies are therefore required to clarify the expression of certain transcriptional factors such as Brn-2 in the pituitary tumor of our case.

Immunohistochemistry demonstrated vasopressin $\mathrm{V} 1 \mathrm{~b}$ receptor in the tumor tissue. It is tempting to speculate that DDAVP might act on V1b receptor expressed in the adenoma and CRF, Ucn1 and Ucn3 secreted from the pituitary adenoma might act on normal corticotroph cells in non-neoplastic portion of the pituitary gland in the paracrine fashion. CRF and Ucn1 bind to both CRF1R and CRF2R, whereas Ucn3 is a specific ligand to CRF2R. CRF and Ucn1 may therefore stimulate ACTH secretion in this case. In patients with ACTH-producing adenoma, the peak of the ACTH response was observed at 15 min after administration of DDAVP [5, 6]. In our case, the peak of the ACTH response to DDAVP was found at $90 \mathrm{~min}$. This delay of the response might be explained by an interval of the secretion of CRF and/or urocortins in response to DDAVP and their subsequent paracrine action on normal corticotroph cells.

Hypothalamic hormones including CRF, growth hormone-releasing hormone (GH-RH), and gonadotropin-releasing hormone (Gn-RH) are expressed in normal pituitary and pituitary tumors [23, 26-29]. Xu et al. [23] reported that CRF mRNA signal intensity of in situ hybridization of pituitary corticotroph adenoma cells was linearly correlated with Ki-67 tumor growth fractions and suggested that CRF expressed in pituitary corticotroph adenomas is an important fac- 
tor associated with a proliferative potential of these tumors. Furthermore, GH-RH mRNA signal intensity of in situ hybridization was linearly correlated with Ki-67 tumor growth fractions and preoperative serum GH levels in acromegaly-associated pituitary tumors [29]. By contrast, there was no significant linear correlation between CRF mRNA signal intensity and preoperative plasma ACTH levels in pituitary corticotroph adenomas [23]. Basal plasma ACTH levels were not elevated in our case. CRF and Ucn1 expressed in the pituitary tumor tissue of the present case may not therefore affect basal ACTH levels without DDAVP stimulation. The relationship between the CRF family peptides expressed in pituitary tumors and the tumor growth needs further investigations in acromegaly-associated pituitary tumors.

In conclusion, these observations raised the possibility that DDAVP caused an ACTH response, perhaps via the paracrine effects of tumor-derived CRF and Ucn1. When ACTH response to DDAVP is observed in patients with pituitary tumor, not only the direct effect of DDAVP on ACTH secretion, but also a possible involvement of CRF and/or urocortins expressed in the pituitary adenoma, should be considered.

\section{References}

1. Melmed S (2006) Medical progress acromegaly. $N$ Engl J Med 355:2558-2573.

2. Asa SL, Ezzat S (1998) The cytogenesis and pathogenesis of pituitary adenomas. Endocr Rev 19:798-827.

3. Nieman LK, Biller BMK, Findling JW, Newell-Price J, Savage MO, Stewart PM, Montori VM (2008) The diagnosis of Cushing's syndrome: an Endocrine Society Clinical Practice Guideline. J Clin Endocrinl Metab 93:1526-1540

4. Moro M, Putignano P, Losa M, Invitti C, Maraschini C, Cavagnini F (2000) The desmopressin test in the differential diagnosis between Cushing's disease and pseudoCushing state. J Clin Endocrinol Metab 85:3569-3574.

5. Pecori Giraldi F, Pivonello R, Ambrogio AG, De Martino MC, De Martin M, Scacchi M, Colao A, Toja PM, Lombardi G, Cavagnini F (2007) The dexamathasone-suppressed corticotropi-releasing hormone stimulation test and the desmopressin test to distinguish Cushing's syndrome from pseudo-Cushing's state. Clin Endocrinol (Oxf) 66:251-257.

6. Sakai Y, Horiba N, Tozawa F, Sakai K, Kuwayama A, Demura H, Suda T (1997) Desmopressin stimulating test for diagnosis of ACTH-dependant Cushing's syndrome. Endocr J 44:687-695.

7. Suda T, Kageyama K, Nigawara T, Sakihara S (2009) Evaluation of diagnostic tests for ACTH-dependent Cushing's syndrome. Endocr J 56:469-476.

8. Oki Y, Hashimoto K, Hitata Y, Iwasaki Y, Nigawara T, Doi M, Sakihara S, Kageyama K, Suda T (2009) Development and validation of a $0.5 \mathrm{mg}$ dexamethasone suppression test as an initial screening test for the diagnosis of ACTH-dependent Cushing's syndrome. Endocr J 56:897-904.

9. Vaughan J, Donaldson C, Bittencourt J, Perrin $\mathrm{MH}$, Lewis K, Sutton S, Chan R, Turnbull AV, Lovejoy D, Rivier C, Rivier J, Sawchenko PE, Vale W (1995) Urocortin, a mammalian neuropeptode related to fish urotensin I and to corticotropin-releasing factor. Nature 378:287-292.

10. Lewis K, Li C, Perrin MH, Blount A, Kunitake K, Donaldson C, Vaughan J, Reyes TM, Gulyas J, Fischer W, Bilezikjian L, River J, Sawchenko PE, Vale WW (2001) Identification of urocottin III, an additional member of the corticotropin-releasing factor (CRF) family with high affinity for the CRF2 receptor. Proc Natl Acad Sci USA 98:7570-7575.

11. Iino K, Sasano H, Oki Y, Andoh N, Shin RW, Kitamoto T, Totsune K, Takahashi K, Suzuki H, Nagura H, Yoshimi T (1997) Urocortin expression in human pituitary gland and pituitary adenoma. J Clin Endocrinol Metab 82:3842-3850.

12. Kimura Y, Takahashi K, Totsune K, Muramatsu Y, Kaneko C, Darnel AD, Suzuki T, Ebina M, Nukiwa T, Sasano H (2002) Expression of urocortin and corticotropin-releasing factor receptor subtypes in the human heart. J Clin Endocrinol Metab 87:340-346.

13. Takahashi K, Totsune K, Murakami O, Saruta M, Nakabayashi M, Suzuki T, Sasano H, Shibahara S (2004) Expression of urocortin III/stresscopin in human heart and kidney. J Clin Endocrinol Metab 89:18971903.

14. Chen R, Lewis KA, Perrin MH, Vale WW (1993) Expression cloning of a human corticotropin-releasingfactor receptor. Proc Natl Acad Sci USA 90:8967-8971.

15. Lovenberg TW, Liaw CW, Grigoriadis DE, Clevenger W, Chalmers DT, De Souza EB, Oltersdorf T (1995) Cloninig and characterization of a functionally distinct corticotropin-releasing factor receptor subtype from rat brain. Proc Natl Acad Sci USA 92:836-840.

16. Donaldson CJ, Sutton SW, Perrin MH, Corrigan AZ, Lewis KA, Rivier JE, Vaughan JM, Vale WW (1996) Cloning and characterization of human urocortin. Endocrinology 137:2167-2170.

17. Smith GW, Aubry JM, Dellu F, Contarino A, Bilezikjian 
LM, Gold LH, Chen R, Marchuk Y, Hauser C, Bentley CA, Sawchenko PE, Koob GF, Vale W, Lee KF (1998) Corticotropin releasing factor receptor 1-deficient mice display decreased anxiety, impaired stress response, and abberant nouroendocrine development. Neuron 20:1093-1102.

18. Murakami O, Takahashi K, Sone M, Totsune K, Ohneda M, Itoi K, Yoshinaga K, Mouri T (1993) An ACTHsecreting bronchial carcinoid: presence of corticotropinreleasing hormone, neuropeptide Y and endothelin-1 in the tumor tissue. Acta Endocrinol (Copenh) 128:192196.

19. Takahashi K, Totsune K, Sone M, Murakami O, Satoh F, Arihara Z, Sasano H, Iino K, Mouri T (1998) Regional distribution of urocortin-like immunoreactivity and expression of urocortin mRNA in the human brain. Peptides 19:643-647.

20. Yamada S, Ohyama K, Taguchi M, Takeshita A, Morita K, Takano K, Sano T (2007) A study of the correlation between morphological findings and biological activities in clinically nonfunctioning pituitary adenomas. Neurosurgery 61:580-584.

21. Wong ML, al-Shekhlee A, Bongiorno PB, Esposito A, Khatri P, Sternberg EM, Gold PW, Licinio J (1996) Localization of urocortin messenger RNA in rat brain and pituitary. Mol Psychiatry 1:307-312.

22. Pecori Giraldi F, Cavagnini F (1998) Corticotropinreleasing hormone is produced by rat corticotropes and modulates ACTH secretion in a paracrine/autocrine fashion. J Clin Invest 101:2478-2484.

23. Xu B, Sano T, Yamada S, Li CC, Hirokawa M (2000) Expression of corticotropin-releasing hormone messenger ribonucleic acid in human pituitary corticotroph adenomas associated with proliferetive potential. J Clin
Endocrinol Metab 85:1220-1225.

24. Tahara S, Kurotani R, Ishii Y, Sanno N, Teramoto A, Osamura Y (2002) A case of Cushing's disease caused by pituitary adenoma producing adrenocorticotropic hormone and growth hormone concomitantly: aberrant expression of transcription factors neuroD1 and Pit-1as a proposed mechanism. Mod Pathol 15:1102-1105.

25. Nakai S, Kawano H, Yudate T, Nishi M, Kuno J, Nagata A, Jishage K, Hamada H, Fujii H, Kawamura K, Shiba K, Noda T (1995) The POU domain transcription factor Brn-2 is required for the determination of specific neuronal lineages in the hypothalamus of the mouse. Genes Dev 9:3109-3121.

26. Wakabayashi I, Inokuchi K, Hasegawa O, Sugihara H, Minami S (1992) Expression of growth hormone (GH)releasing factor gene in GH-producing pituitary adenoma. J Clin Endocrinol Metab 74:357-361.

27. Levy A, Lightman SL (1992) Growth hormone-releasing hormone transcripts in human pituitary adenomas. $J$ Clin Endocrinol Metab 74:1474-1476.

28. Sanno N, Jin L, Qian X, Osamura RY, Scheithauer BW, Kovacs K, Lloyd RV (1997) Gonadotropin-releasing hormone and gonadotropin-releasing hormone receptor messenger ribonucleic acids expression in nontumorous and neoplastic pituitaries. J Clin Endocrinol Metab 82:1974-1782.

29. Thapar K, Kovacs K, Stefaneanu L, Scheithauer B, Killinger DW, Lioyd RV, Smyth HS, Barr A, Thorner MO, Gaylinn B, Laws ER Jr (1997) Overexpression of the growth-hormone-releasing hormone gene in acromegaly-associated pituitary tumors. An event associated with neoplastic progression and aggressive behavior. Am J Pathol 151:769-784. 